$78: 584$

<症例報告 $>$

腫瘍結節間の HBV-DNA 組み込みパターンに差異が

見られた興味ある肝細胞癌の 1 剖検例

\author{
安井 英明* 長谷川章雄* 樋野 興夫** \\ 志賀 淳治* 町並 陸生*
}

\begin{abstract}
要 旨：B 型肝炎ウイルス carrier から発症した肉眼分類上は Eggel の塊状型肝細胞癌で, 採 取された複数腫癔結節間において，異なるウイルスDNAの組み込みパターンが見られた興味 ある 1 例を経験したので報告する，症例は22歳，女性. 昭和62年 1 月に腹部腫瘤を自覚し, 某 病院へ入院した。腹部超音波画像診断にて多発性肝占拠性病变を指摘され, $\boldsymbol{\alpha}$-fetoprotein が高 值を示したため, 肝細胞癌の診断を受けた，昭和62年 4 月東大病院に転院し LAK, IL-2療法に て治療したが，肝不全が進行し，昭和63年 1 月に死亡した．剖検時, 肝は肉眼的に Eggel の塊 状型肝細胞癌の像を呈しており，無作為に10個の腫瘍結節を選び, DNAを抽出し HBV-DNA の組み込みを検索したところ，8個については同一の組み込みパターンが見られたが，残りの 2 個については組み込みが認められなかった.
\end{abstract}

索引用語： 肝細胞癌 HBV-DNA integration

はじめに

多結節状を呈する旰細胞癌は, 単中心性に発生した 肝細胞癌が肝内転移結節を形成したものか，それとも 多中心性に発生した肝細胞癌が多結節性病变を形成し たものであるのか, 病理学的に大変興味ある問題であ る. 一方, B 型肝炎ウイルスキ+リフー( $\mathrm{HBV} キ+1)$ アー)から発生した肝細胞癌においては，癌細胞 DNA 内に高率に HBV-DNAが組み込まれており，その存 在様式から, 肝細胞癌はクローナルな細胞增生であり， ウイルスの組み込みは，肝癌発生以前の出来事である ことが証明されている1ー3)。

そこで，HBVキャリてに発生した肝細胞癌におい て, 复数の癌結節を採取し, HBV-DNA の組み込みハ: タージ異同を調べことにより，多結節状を呈する 肝細胞癌が単中心性に発生したるのか，あるいは多中 心性発生であるかを検討することができると考えられ る.さらに複数の腫湯結節間において HBV-DNAの 組み込みパターンが異なる場合, 本来は単中心性であ るが，HBV-DNA 組み込み後に DNAの再編成が起 こったすのであるのか，具体的に論ずることが可能と なってきた，今回私共はこのような立場に基づき，肉

* 東京大学医学部病理学教室

** 癌研究所病理部

〈受付日1988年11月 7 日 >
眼的に Eggel の塊状型肝細胞癌から, 複数腫匐結節を 採取しHBV-DNA を検索したところ，嗹場結節間に おけるHBV-DNA の組み込みパターンが明らかに異 なる興味ある 1例を経験したので報告する。

症例

患者：22歳，女性.

主訴：腹部腫瘤.

既往歴：なし。

家族歴：父方祖父が肝細胞癌にて死亡している:

現病歴：腹部隀瘤を自覚し, 昭和62年 1 月に, 某医 科大学病院へ入院した．腹部超音波画像診断にて，多 発性肝占抛性病変を指摘され, AFP : $80,000 \mathrm{ng} / \mathrm{m} l$ と 高值を示したため，肝細胞癌と診断され，4月に東大 病院に入院した。

入院時現症：身長 $163.5 \mathrm{~cm}$, 体重 $62.3 \mathrm{~kg}$, 肝は腹部 正中剣状突起下 7 横指触知し, 腹水の眝留を認めた。 また眼球結膜に黄染なし。

検查成績 (Table)：血液生化学検査では，ビリルビ ン, $\boldsymbol{\gamma}$-GTP, Al-P の上昇など, 肝機能異常が見られた。 HBV マーカーに関しては, HBs 抗原, HBe 抗体, HBc 抗体陽性で, HBe 抗原陰性であった。 また AFP： $72,000 \mathrm{ng} / \mathrm{m} l$ と高值を示した。

入院後経過：LAK, IL-2療法にて, AFP : 27,000ng/ $\mathrm{m} l$ と低下し， 6 月に一旦退院した。 7 月に再入院し， 
以後 LAK, IL-2療法を反復施行したが, AFP 值は次第 に上昇し， 9 月には $100,000 \mathrm{ng} / \mathrm{m} l$ となった。 11 月より 直接ビリルビンが上昇し，さらに腹水も出現した。 12 月には AFP 値が $140,000 \mathrm{ng} / \mathrm{m} l$ K上昇し, 昭和63年 1 月, 肝不全にて死亡した.

\section{1) 肉眼所見}

\section{剖検所見}

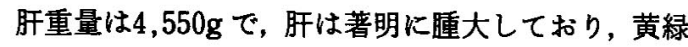
色調を呈していた。割面では，最大径 $4 \mathrm{~cm}$ までの黄白 色重煌結節が瘜合して, $19 \times 17 \times 10 \mathrm{~cm}$ 大の不整形地 図状腫瘤を形成し，右葉のほぼ全体を占めていた。さ

Table Laboratory data on admission.

\begin{tabular}{lc|ll}
\hline \multicolumn{2}{l|}{ Blood examination } & T.Protein & $6.0 \mathrm{~g} / \mathrm{d} l$ \\
RBC & $443 \times 10^{4} / \mathrm{mm}^{3}$ & Albumin & $3.1 \mathrm{~g} / \mathrm{d} l$ \\
WBC & $7100 / \mathrm{mm}^{3}$ & T.bil. & $1.2 \mathrm{mg} / \mathrm{d} l$ \\
Platelet & $15.0 \times 10^{4} / \mathrm{mm}^{3}$ & D.bil. & $0.4 \mathrm{mg} / \mathrm{d} l$ \\
Hb & $12.4 \mathrm{~g} / \mathrm{d} l$ & GOT & $33 \mathrm{KU}$ \\
P.T. & $37.9 \%$ & GPT & $13 \mathrm{KU}$ \\
Fibrinogen & $146 \mathrm{mg} / \mathrm{d} l$ & LDH & $145 \mathrm{U} / l$ \\
Blood chemistry & r-GTP & $117 \mathrm{U} / l$ \\
$\mathrm{Na}$ & $140 \mathrm{mEq} / l$ & Al-P & $325 \mathrm{U} / l$ \\
$\mathrm{~K}$ & $3.9 \mathrm{mEq} / l$ & Serological data \\
$\mathrm{Cl}$ & $109 \mathrm{mEq} / l$ & AFP & $72000 \mathrm{ng} / \mathrm{m} l$ \\
$\mathrm{Ca}$ & $9.6 \mathrm{mg} / \mathrm{d} l$ & HBsAg & $(+)$ \\
P & $3.4 \mathrm{mg} / \mathrm{d} l$ & HBsAb & $(-)$ \\
BUN & $9 \mathrm{mg} / \mathrm{d} l$ & HBeAg & $(-)$ \\
Creatinine & $0.5 \mathrm{mg} / \mathrm{d} l$ & HBeAb & $(+)$ \\
Uric acid & $3.4 \mathrm{mg} / \mathrm{d} l$ & HBcAb & $(+)$ \\
\hline
\end{tabular}

らに，左葉には最大径 $3 \mathrm{~cm}$ までの結節が多数認めら れ, Eggel の分類による塊状型肝細胞癌と判断された4 (Fig. 1).腫瘍は胆票壁に直接浸潤するとともに, 両側 肺に多発性転移結節を形成していたが，リンパ節転移 および門脈主幹分枝への腫㷎栓は認められなかった。 非腫瘍部には胆汁うっ滞が目立ったが，これは腫場に よる肝内胆管の閉塞のためと考劣られた。

\section{2）肝組織所見および HBV-DNA 組み込み}

肝左右両葉より，無作為に10個の腫場結節 (Fig. 2), 5 個の非腫簜部, さらに肺転移結節 1 個を選び, $\mathrm{HE}$ 標 本を作成するとともに, DNAを抽出し，制限酵素 Hind III および Bam HIにて切断後，サザン法により

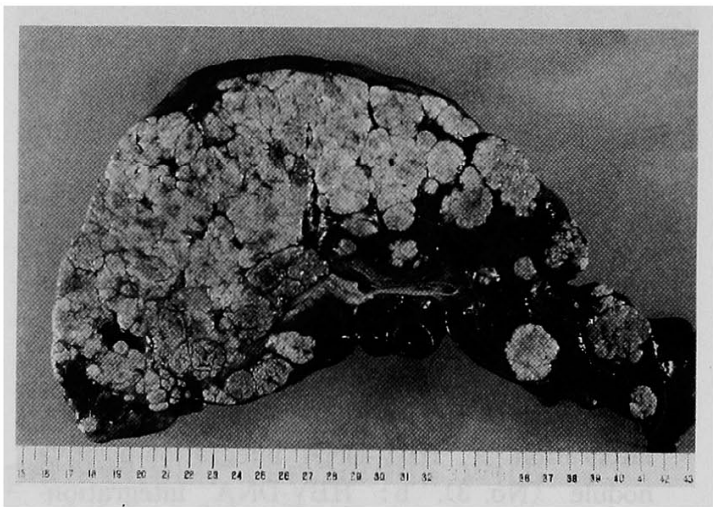

Fig. 1 The cut surface of the liver shows massive and nodular tumors mainly occupying the right lobe of the liver.

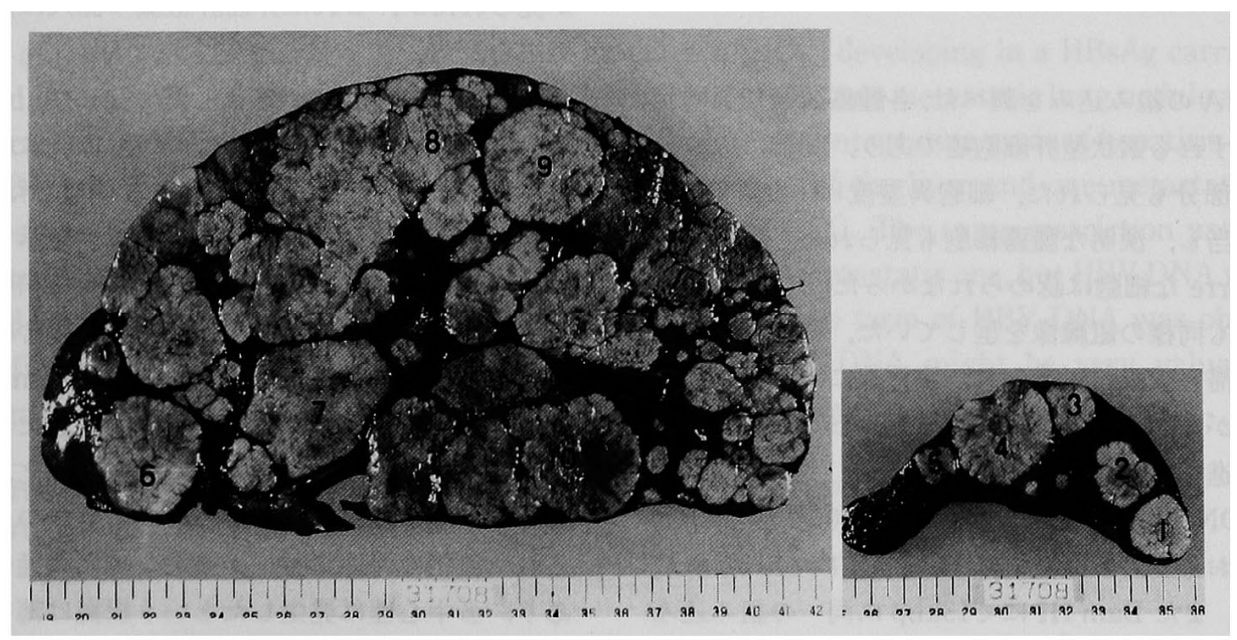

Fig. 2 This cut surface of the liver shows multiple tumor nodules replacing the liver parenchyma. The figures from 1 to 10 indicate locations of the samples for Southern blot analysis. 


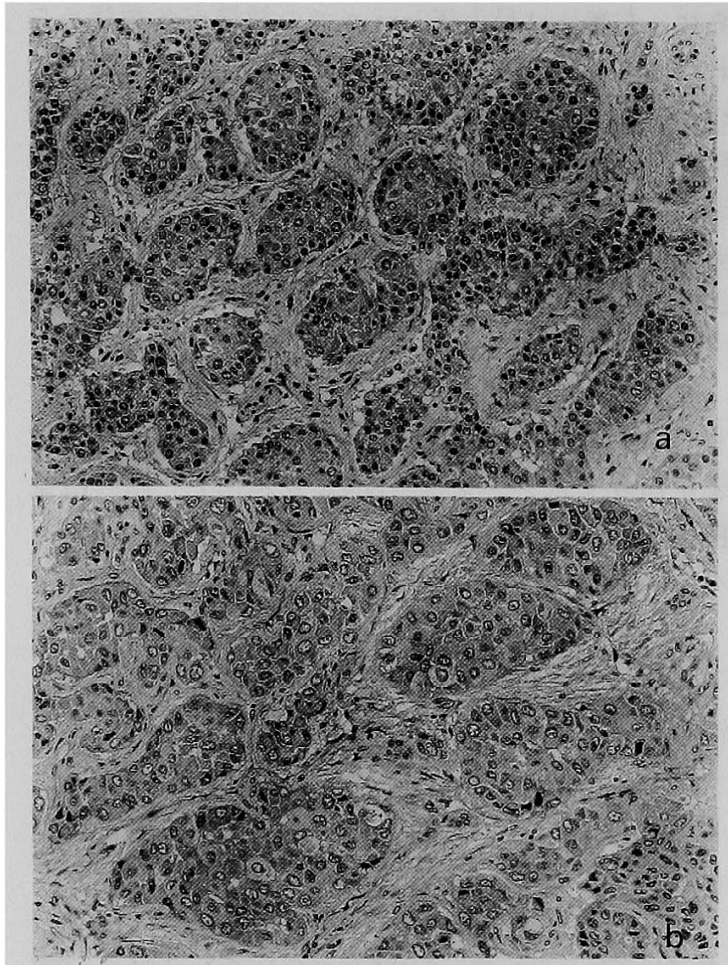

Fig. 3 Comparative histological appearance of the nodules of $\mathrm{HCC}$ with and without HBV.DNA integration. a: HBV-DNA integration-positive nodule (No. 3). b: HBV-DNA integrationnegative nodule (No. 8). Both nodules show hepatocellular carcinoma of trabecular pattern partly with sclerosis. (HE stain. a : $\times 100, \mathrm{~b}: \times$ 140)

HBV-DNAの組み込みを調べた. 各腫湯結節10個の組 織像はいずれす索状型肝細胞癌であり，間質に線維化 が目立つ部分も見られた。細胞型型度は Edmondson II 型に相当し，淡明な腫瘍細胞も見られた。腫場巨細 胞や bizarre な細胞は認められなかった(Fig. 3a, b). 肺転移巣も同様の組織像を呈していた。非癌部には胆 汁のうっ滞と線維化が見られ，壊死部には著明な偽胆 管の増生があり, 円形細胞浸潤も認められたが, 肝硬 変までは進行していなかった。

HBV-DNAの組み込みについては, 10個の腫㕫結節 中 8 個，および肺転移巣では Hind III にて5.3kbpに (Fig. 4)，また Bam HIにて13kbpに同一の組み込み パターンが見られたが, 興味あることに, 残りの 2 個 （腫瘍結節 No. 8,9)に扔いては組み込みが認められな かった。血清 $\mathrm{HBe}$ 抗体陽性にもかかからず, 非癌部肝
30 巻 5 号 (1989)

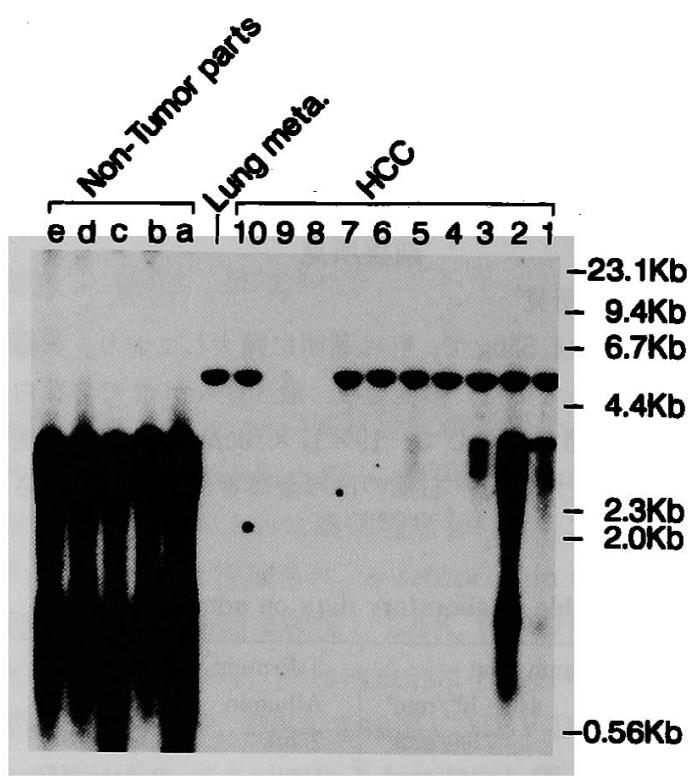

Fig. 4 Autoradiograph of Southern blot analysis after digestion with Hind III and hybridized with a cloned ${ }^{32} \mathrm{p}-\mathrm{HBV}$-DNA covering the entire virus genome. DNA was extracted from ten tumor nodules, one metastatic lung nodule and five noncancerous portions. Molecular weight markers of known length are shown on the right.

組織においてはいずれも複製中の遊離の HBV-DNA が存在していた。

また腫瘍結節 No. 1，2，3，5にも遊離の HBV-DNA が見られたが，これは非癌肝組織の混入によるものと 考えられた。

\section{考察}

肝癌のクローナリティーについては既にいくつかの 報告があり, 肝内数力所の癌部より採取した DNA は， サザン法にて同一の組み込みパターンを示すことが確 認されている ${ }^{2,3,6)}$.このことは，大部分の肝癌は，一見 多中心性に発生した様に見えるるの 心性であることを示している、一方, Esumi らかは, 14 例の肝癌のらち 1 例において, 調べられた 4 腫瘍結節 中 1 結節に他の 3 結節と同じバンドに加え, 異なる付 加のバンドを観察している. しかし付加のパンドが見 られた症例においてむ，4結節全てに共通のパンドが あり，多中心性に発生したといら根拠は薄いよらに思 光る。

本症例は, 肉眼分類上, Eggel の塊状型と考えられた 肝細胞癌で，10個の尰暘結節中 2 個において, HBV- 
DNAの組み込みが全く認められなかった。 その説明 として, (1)この 2 結節においては, HBV-DNA の組み 込みのない別の肝細胞から肝癌が発生した。(2)本来, HBV.DNA の組み込みのある同一のクローンから発 生した肝癌であるが，この 2 結節の由来した肝細胞が 増殖する過程で, 組み込み DNA が完全に久落した, と いう二つの可能性が考えられる，本症例で観察された HBV-DNA 組み迈みパターンの差異は肝細胞癌発生 及び, 遺伝子再編成の問題に, 貴重な示唆を与兄るる のと考えられる。

現在, 分子クローニングにより,この問題を検討中 である.

なお，本研究は厚生省癌研究助成金，「肝の微小癌と境界 病変に関する研究」および厚生省班研究, 「難治性の肝炎」 調查研究班の助成によった。

\section{文 献}

1) Bréchot C, Pourcel C, Louise A, et al: Presence of integrated hepatitis $B$ virus DNA sequences in cellular DNA of human hepatocel: lular carcinoma. Nature 286 : 533-535, 1980
2) Shafritz DA, Shouval D, Sherman HI, et al: Integration of hepatitis $B$ virus DNA into the genome of liver cells in chronic liver disease and hepatocellular carcinoma. $\mathrm{N}$ Engl $\mathrm{J}$ Med 305 : 1067-1073, 1981

3) Hino $O$, Kitagawa $T$, Sugano $H$ : Relationship between serum and histochemical markers for hepatitis $B$ virus and rate of viral integration in hepatocellular carcinoma in Japan. Int J Cancer $35: 5-10,1985$

4) Eggel $\mathrm{H}$ : Ueber das primäre Carcinom der Leber. Beitr z Path Anat u $z$ allgem Pathol 30 : 506-604, 1901

5) Esumi M, Aritaka T, Arii $M$, et al: Clonal origin of human hepatoma determined by integration of hepatitis B virus DNA. Cancer Res 46: 5767-5771, 1986

6) Govindarajan S, Craig JR, Valinluck B : Clonal origin of hepatitis $\mathrm{B}$ virus-associated hepatocellular carcinoma. Human Pathol 19 : 403-405, 1988

\title{
An autopsy case of massive hepatocellular carcinoma with different integration mode of hepatitis $B$ virus DNA in several tumor nodules
}

\author{
Hideaki YASUI*, Akio HaSEgawa*, Okio Hino**, Junji ShigA* and Rikuo MACHINAM*
}

An autopsy case of massive hepatocellular carcinoma (HCC) developing in a HBsAg carrier was reported. At autopsy, DNA was extracted from ten tumor nodules, one metastatic lung nodule and five noncancerous portions of the liver to investigate the presence and integration mode of hepatitis $B$ virus (HBV) DNA by Southern blot analysis. All ten tumor nodules of the liver and one metastatic lung nodule showed the same histological features of trabecular HCC. The same restriction pattern of integrated HBV DNA was detected in eight tumor nodules and a metastatic one, but HBV DNA was not detected in two tumor nodules. In noncancerous portions a free form of HBV DNA was observed. These findings suggest that Southern blot analysis of HBV DNA might be very valuable for investigation of the genesis and post-integration DNA rearrengements of HCC.

\footnotetext{
* Department of Pathology, Faculty of Medicine, University of Tokyo (Tokyo)

** Department of Pathology, Cancer Institute (Tokyo)
} 